\title{
Captopril protects against burn-induced cardiopulmonary injury in rats
}

\author{
Esra Sağlam, M.D., ${ }^{1}$ Ahmet Özer Şehirli, PhD., ${ }^{2}$ Emine Nur Özdamar, M.D., ${ }^{3}$ Gazi Contuk, PhD., ${ }^{4}$ \\ Şule Çetinel, M.D., ${ }^{4}$ Derya Özsavcı, PhD., ${ }^{5}$ Selami Süleymanoğlu, M.D., ${ }^{6}$ Göksel Şener, PhD. ${ }^{2}$
}

\author{
${ }^{1}$ Maltepe University, School of Medicine, Department of Pharmacology and Clinical Pharmacology, Istanbul \\ ${ }^{2}$ Department of Pharmacology, Marmara University Faculty of Pharmacy, Istanbul \\ ${ }^{3}$ Department of Medical Pharmacology, Marmara University Faculty of Medicine, Istanbul \\ ${ }^{4}$ Department of Histology \& Embryology, Marmara University Faculty of Medicine, Istanbul \\ ${ }^{5}$ Department of Biochemistry, Marmara University Faculty of Pharmacy, Istanbul \\ ${ }^{6}$ Department of Cardiology, Gulhane Military Medical Academy, Istanbul
}

\begin{abstract}
BACKGROUND: This study was designed to determine the possible protective effect of captopril treatment against oxidative damage in heart and lung tissues induced by burn injury.

METHODS: Under ether anesthesia, the shaved dorsum of Wistar albino rats was exposed to $90^{\circ} \mathrm{C}$ water bath for 10 seconds. Captopril was administered intraperitoneally $(10 \mathrm{mg} / \mathrm{kg})$ after the burn injury and repeated twice daily. In the sham group, the dorsum was dipped in a $25^{\circ} \mathrm{C}$ water bath for 10 seconds. At the end of the 24 hours, echocardiographic recordings were performed, then animals were decapitated and heart and lung tissue samples were taken for the determination of tumor necrosis factor- $\alpha$ (TNF- $\alpha$ ) as a pro-inflammatory cytokine, malondialdehyde and glutathione levels and myeloperoxidase, caspase-3, and $\mathrm{Na}^{+}, \mathrm{K}^{+}-\mathrm{ATPase}^{-}$activity in addition to the histological analysis.
\end{abstract}

RESULTS: Burn injury caused significant alterations in left ventricular function. In heart and lung tissues, TNF- $\alpha$ and malondialdehyde levels and myeloperoxidase and caspase- 3 activities were found to be increased, while glutathione levels and $\mathrm{Na}^{+}, \mathrm{K}^{+}-\mathrm{ATPase}$ activity were decreased due to burn injury. Captopril treatment significantly elevated the reduced glutathione level and $\mathrm{Na}^{+}, \mathrm{K}^{+}-\mathrm{ATPase}$ activity, and decreased cytokine and malondialdehyde levels and myeloperoxidase and caspase- 3 activities.

CONCLUSION: Captopril prevents burn-induced damage in heart and lung tissues and protects against oxidative organ damage.

Key words: Captopril; cytokine; lipid peroxidation; myeloperoxidase; thermal trauma.

\section{INTRODUCTION}

Thermal trauma produces profound systemic changes such as oligemic shock, anemia, renal failure, and metabolic disturbances. It causes direct tissue damage as well as inflammatory reactions. ${ }^{[I]}$ Thermal trauma causes a progressive decrease in cardiac output and cardiac stroke volume, release of vasocon-

Address for correspondence: Esra Saglam, M.D.

Alemdağ Cad., Site Yolu, No: 27, Ümraniye, İstanbul, Turkey

Tel: +90 216 - 6330633 E-mail: esra.k.saglam@gmail.com

Qucik Response Code Ulus Travma Acil Cerrahi Derg

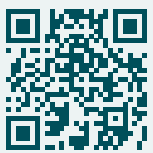

2014;20(3):151-160

doi: $10.5505 /$ tites.2014.96493

Copyright 2014

TJTES strictor mediators such as vasopressin, altered baroreceptor and chemoreceptor reflexes, and reabsorption of fluid. ${ }^{[2]} A$ number of experimental and clinical studies have shown that, despite aggressive fluid resuscitation and maintenance of pulmonary capillary wedge pressure, stroke work and ejection fraction (EF) often decrease after thermal trauma. ${ }^{[3,4]}$ Several studies have indicated that decreased cardiac contractility is one of the important mechanisms for decreased cardiac output and cardiac dysfunction after severe thermal trauma. ${ }^{[5,6]}$

Angiotensin converting enzyme (ACE) catalyzes the conversion of angiotensin I (Ang I) to angiotensin II (Ang II). ACE also cleaves the terminal dipeptide of vasodilating hormone bradykinin to inactivate this hormone. Hyperactivity of the reninangiotensin system (RAS), an endocrine system with critical roles in cardiovascular function, has been implicated in the etiology of high blood pressure, obesity and metabolic syndrome. [7] Therefore, inhibition of ACE is generally used as one of the 
methods in the treatment of hypertension and chronic inflammation. ${ }^{[8,9]}$ Pharmacologically, it is known that ACE inhibitors containing a sulfhydryl or a thiol radical, such as the orally active compound captopril, have an antioxidant activity. ${ }^{[10,11]}$

In the light of these findings, we hypothesized that captopril would provide protection against burn-induced cardiopulmonary damage. We aimed to investigate whether and to what extent captopril reduces this damage, by determining the presence of oxidative tissue injury using biochemical and histological parameters.

\section{MATERIALS AND METHODS}

Animals

Wistar albino rats of both sexes, weighing 200-250 g, were obtained from Marmara University School of Medicine Animal House. The rats were kept at a constant temperature $\left(22 \pm I^{\circ} \mathrm{C}\right)$ with 12-hour (h) light and dark cycles, fed with standard rat chow, and fasted for $12 \mathrm{~h}$ before the experiments, but were allowed free access to water. All experimental protocols were approved by the Marmara University Animal Care and Use Committee.

\section{Thermal Injury and Experimental Design}

This is a randomized controlled trial. All groups were elected in exactly the same way. Twenty-four animals were divided into three groups of eight rats each: One group served as controls. Two groups underwent burn injury and were treated with saline or captopril. Under brief ether anesthesia, the dorsum of the rats was shaved and exposed to $90^{\circ}$ water bath for 10 seconds (s), which resulted in a second-degree burn involving $30 \%$ of the total body surface area. ${ }^{[2]}$ To rule out the effects of the anesthesia, the same protocol was applied in the control group, except that the dorsa were dipped in a $25^{\circ} \mathrm{C}$ water bath for $10 \mathrm{~s}$. After sham or burn injury, rats were resuscitated with physiological saline solution $(10 \mathrm{ml} /$ $\mathrm{kg}$ subcutaneous). ACE inhibitor captopril (10 mg/kg, intraperitoneal (i.p.); Sigma-Aldrich; St. Louis, MO, USA) or saline was given intraperitoneally to rats immediately after the burn injury, and the injections were repeated twice a day. Two groups (controls and the first burn group) received saline and the second burn group received i.p. captopril (10 $\mathrm{mg} / \mathrm{kg}$ in saline) administered immediately after the burn, and the injections were repeated twice a day. Intraperitoneal administration of captopril could potentially have a systemic effect. ${ }^{[13]}$ In both the saline- and captopril-treated burn groups, rats were decapitated at $24 \mathrm{~h}$ following burn injury. At the end of the experimental period, transthoracic echocardiography was performed to assess the cardiac function of the rats. Then, the animals were decapitated in order to evaluate the presence of oxidant injury in the heart, and lung tissue samples were taken and stored at $-80^{\circ} \mathrm{C}$ for the determination of pro-inflammatory cytokine [tumor necrosis factor- $\alpha$ (TNF- $\alpha$ )], malondialdehyde (MDA) and glutathione (GSH) levels and myeloperoxidase (MPO) and $\mathrm{Na}^{+}, \mathrm{K}^{+}$-ATPase and caspase- 3 activities. For histological analysis, samples of the tissues were fixed in $10 \%$ (vol/vol) buffered $\mathrm{p}$-formaldehyde and prepared for routine paraffin embedding. Tissue sections $(6 \mu \mathrm{m})$ were stained with hematoxylin and eosin (H\&E) and examined under a light microscope (Olympus-BH-2). An experienced histologist who was unaware of the treatment conditions performed the histological assessments.

\section{Echocardiography}

Echocardiographic imaging and calculations were done according to the guidelines published by the American Society of Echocardiography ${ }^{[14]}$ using a $12 \mathrm{MHz}$ linear transducer and 5-8 MHz sector transducer (Vivid 3, General Electric Medical Systems Ultrasound, Tirat Carmel, Israel). Under ketamine (50 mg/kg, i.p.) anesthesia, measurements were made from M-mode and two-dimensional images obtained in the parasternal long- and short axes at the level of the papillary muscles after observation of at least six cardiac cycles. Interventricular septal thickness (IVS), left ventricular diameter (LVD) and left ventricular posterior wall thickness (LVPW) were measured during systole (s) and diastole (d). EF, fractional shortening (FS) and left ventricular mass (LVM) and relative wall thickness (RWT) were calculated from the M-mode images using the following formulas: \% $E F=\left[(L V D d)^{3}-(L V D s)^{3} /\right.$ $\left.(\mathrm{LVDd})^{3} \times 100\right], \% \mathrm{FS}=$ [LVDd-LVDs/LVDd $\left.\times 100\right], \mathrm{LVM}=$ $\left[1.04 \times\left((\text { LVDd+LVPWd+IVSd })^{3}-(\text { LVDd })^{3}\right) \times 0.8+0.14\right]$, and RWT $=[2 \times($ LVPWd/LVDd $)]$.

\section{Determination of Tissue TNF- $\alpha$ Levels:}

The levels of TNF- $\alpha$ in the tissues were measured by enzyme-linked immunosorbent assay (ELISA). Heart and lung tissues (100 mg) were homogenized in an ice-cold bath. After centrifugation, the supernatant was collected and total protein content was determined. Tissue TNF- $\alpha$ levels were measured with rat TNF- $\alpha$ ELISA kits (Invitrogen; Taastrup, Denmark) according to the manufacturer's instructions. Absorbance of standards and samples was determined on a plate reader at $405 \mathrm{~nm}$. Results are expressed as pg/I00 mg tissue.

\section{Malondialdehyde and Glutathione Assays}

Tissue samples were homogenized with ice-cold $150 \mathrm{mM} \mathrm{KCl}$ for the determination of MDA and GSH levels. The MDA levels were assayed for products of lipid peroxidation by monitoring thiobarbituric acid reactive substance formation as described previously. ${ }^{[15]}$ Lipid peroxidation was expressed in terms of MDA equivalents using an extinction coefficient of $1.56 \times 10^{5} \mathrm{M}^{-1} \mathrm{~cm}^{-1}$, and results are expressed as $\mathrm{nmol} \mathrm{MDA} / \mathrm{g}$ tissue. GSH measurements were performed using a modification of the Ellman procedure. ${ }^{[16]}$ Briefly, after centrifugation at $3000 \mathrm{rev} / \mathrm{minute}(\mathrm{min})$ for $10 \mathrm{~min}, 0.5 \mathrm{ml}$ of supernatant was added to $2 \mathrm{ml}$ of $0.3 \mathrm{~mol} / \mathrm{L} \mathrm{Na} \mathrm{HPO}_{4} \cdot 2 \mathrm{H}_{2} \mathrm{O}$ solution. A 0.2 $\mathrm{ml}$ solution of dithiobisnitrobenzoate $(0.4 \mathrm{mg} / \mathrm{ml} \mathrm{I} \%$ sodium citrate) was added, and the absorbance at $412 \mathrm{~nm}$ was measured immediately after mixing. GSH levels were calculated 
using an extinction coefficient of $1.36 \times 10^{4} \mathrm{M}^{-1} \mathrm{~cm}^{-1}$. Results are expressed in $\mu \mathrm{mol} \mathrm{GSH} / \mathrm{g}$ tissue.

\section{Myeloperoxidase Activity}

Myeloperoxidase (MPO) is an enzyme found predominantly in the azurophilic granules of polymorphonuclear leukocytes (PMN). Tissue MPO activity is frequently utilized to estimate tissue PMN accumulation in inflamed tissues, and correlates significantly with the number of PMN determined histochemically in tissues. MPO activity was measured in tissues in a procedure similar to that documented by Hillegass et al. ${ }^{[17]}$ Tissue samples were homogenized in $50 \mathrm{mM}$ potassium phosphate buffer (PB, $\mathrm{pH} 6.0$ ), and centrifuged at 4l,400 g (10 min); pellets were suspended in $50 \mathrm{mM}$ PB containing $0.5 \%$ hexadecyltrimethylammonium bromide (HETAB). After three freeze and thaw cycles, with sonication between cycles, the samples were centrifuged at 4I,400 g for $10 \mathrm{~min}$. Aliquots $(0.3 \mathrm{ml})$ were added to $2.3 \mathrm{ml}$ of reaction mixture containing $50 \mathrm{mM} \mathrm{PB}$, o-dianisidine, and $20 \mathrm{mM} \mathrm{H}_{2} \mathrm{O}_{2}$ solution. One unit of enzyme activity was defined as the amount of MPO present that caused a change in absorbance measured at $460 \mathrm{~nm}$ for $3 \mathrm{~min}$. MPO activity was expressed as $\mathrm{U} / \mathrm{g}$ tissue.

\section{$\mathrm{Na}^{+}, \mathrm{K}^{+}$-ATPase Activity}

Since the activity of $\mathrm{Na}^{+}, \mathrm{K}^{+}$-ATPase, a membrane-bound enzyme required for cellular transport, is very sensitive to free radical reactions and lipid peroxidation, reductions in this activity can indicate membrane damage indirectly. Measurement of $\mathrm{Na}^{+}, \mathrm{K}^{+}$-ATPase activity is based on the measurement of inorganic phosphate released by ATP hydrolysis during incubation of homogenates with an appropriate medium containing $3 \mathrm{mM}$ ATP as a substrate. The total ATPase activity was determined in the presence of $100 \mathrm{mM} \mathrm{NaCl}, 5 \mathrm{mM} \mathrm{KCl}, 6$ $\mathrm{mM} \mathrm{MgCl}, 0.1 \mathrm{mM}$ EDTA, and $30 \mathrm{mM}$ Tris $\mathrm{HCl}(\mathrm{pH} 7.4)$, while the $\mathrm{Mg}^{2+}$-ATPase activity was determined in the presence of ImM ouabain. The difference between the total and the $\mathrm{Mg}^{2+}$-ATPase activities was taken as a measure of the $\mathrm{Na}^{+}$,
$\mathrm{K}^{+}$-ATPase activity. ${ }^{[18]}$ The reaction was initiated with the addition of the homogenate $(0.1 \mathrm{ml})$, and a 5 -min preincubation period at $37^{\circ} \mathrm{C}$ was allowed. Following the addition of $\mathrm{Na}_{2}$ ATP and a 10-min re-incubation period, the reaction was terminated by the addition of ice-cold $6 \%$ perchloric acid. The mixture was then centrifuged at $3500 \mathrm{~g}$, and $\mathrm{Pi}$ in the supernatant fraction was determined by the method of Fiske and Subarrow. ${ }^{[19]}$ The specific activity of the enzyme was expressed as $\mu \mathrm{mol} \mathrm{Pi} \mathrm{mg}-\mathrm{I}$ protein $\mathrm{h}-\mathrm{I}$. The protein concentration of the supernatant was measured by the Lowry method. ${ }^{[20]}$

\section{Caspase-3 Activity}

Caspase-3 activity was measured using ApoTargetCaspase-3/ CPP32 Colorimetric Protease Assay (Invitrogen; Taastrup, Denmark) kit according to the manufacturer's instructions. Briefly, brain and lung tissue samples were homogenized and treated for 10 min with iced lysis buffer supplied by the manufacturer. The cell lysates were subjected to three freeze and thaw cycles and $2 \times 10$ s sonication to fully disrupt the cells and disperse cell debris. The cell lysate was then centrifuged at 20,000 $\mathrm{g}$ for $5 \mathrm{~min}$ and the supernatant transferred to new Eppendorf tubes. Following protein determination, cytosol extracts were diluted in $50 \mu \mathrm{L}$ lysis buffer and $50 \mu \mathrm{L}$ reaction buffer ( $10 \mathrm{mM}$ dithiothreitol). Samples were added to wells and the microplate was equilibrated at $37^{\circ} \mathrm{C}$ for $10 \mathrm{~min}$. The reaction was initiated by adding $5 \mu$ of DEVD-pNA (AspGlu-Val-Asp p-nitroanilide) substrate (200 $\mu \mathrm{M}$ final concentration), and the reaction was carried out at $37^{\circ} \mathrm{C}$ for $2 \mathrm{~h}$ in the dark. The colorimetric release of $p$-nitroaniline (pNA) from the Ac-DEVD-pNA substrate was recorded at $405 \mathrm{~nm}$ using a microplate reader. Experiments were performed in triplicate. Results are presented as mean \pm SD of six separate experiments and expressed as fold-increase over pretreatment level (untreated samples).

\section{Histopathological Analysis}

For light microscopic investigations, heart and lung specimens

Table I. Transthoracic echocardiography measurements in the experimental groups

\begin{tabular}{|c|c|c|c|}
\hline \multirow[t]{2}{*}{ Parameter } & \multirow{2}{*}{$\frac{\text { Control group }}{\text { Saline-treated }}$} & \multicolumn{2}{|c|}{ Burn group } \\
\hline & & Saline-treated & Captopril-treated \\
\hline Interventricular septal thickness (mm) & $2.36 \pm 0.18$ & $3.01 \pm 0.1 I^{* *}$ & $2.45 \pm 0.08^{+}$ \\
\hline Left ventricular posterior wall thickness $(\mathrm{mm})$ & $1.73 \pm 0.12$ & $2.55 \pm 0.11^{*}$ & $1.77 \pm 0.11^{+}$ \\
\hline Relative wall thickness & $0.66 \pm 0.03$ & $0.98 \pm 0.10^{*}$ & $0.7 I \pm 0.08^{+}$ \\
\hline Left ventricular diameter in systole (mm) & $2.63 \pm 0.27$ & $3.96 \pm 0.15^{* *}$ & $2.98 \pm 0.21^{+}$ \\
\hline Left ventricular diameter in diastole $(\mathrm{mm})$ & $4.09 \pm 0.16$ & $5.18 \pm 0.14 *$ & $4.32 \pm 0.24^{+}$ \\
\hline Ejection fraction $(\%)$ & $79.03 \pm 3.67$ & $63.60 \pm 2.73^{*}$ & $77.78 \pm 3.44^{+}$ \\
\hline Fractional shortening (\%) & $42.27 \pm 3.54$ & $26.61 \pm 2.24^{* *}$ & $39.7 I \pm 3.2 I^{+}$ \\
\hline Heart/body weight ratio (mg/g) & $2.21 \pm 0.12$ & $2.73 \pm 0.08^{* *}$ & $2.29 \pm 0.09^{+}$ \\
\hline
\end{tabular}

Data are the mean \pm SEM of six animals. ${ }^{*} \mathrm{p}<0.05,{ }^{* *} \mathrm{p}<0.01$ compared to saline-treated control group; $+\mathrm{p}<0.05$ compared with the saline-treated burn group. 
were fixed in 10\% buffered formalin for $48 \mathrm{~h}$, dehydrated in an ascending alcohol series, and embedded in paraffin wax. Approximately 5 - $\mu$ m-thick sections were stained with $\mathrm{H} \& \mathrm{E}$ for general morphology. Histological assessments were made with a photomicroscope (Olympus BX 5I; Tokyo) by an experienced histologist who was unaware of the experimental groups.

\section{Statistics}

Statistical analysis was carried out using GraphPad Prism 3.0 (GraphPad Software; San Diego, CA, USA). All data were expressed as means \pm SEM. Groups of data were compared with an analysis of variance (ANOVA) followed by Tukey's multiple comparison tests. Values of $\mathrm{p}<0.05$ were regarded as significant.

\section{RESULTS}

Table I summarizes the transthoracic echocardiography measurements of the experimental groups. In the saline-treated burn group, LVPW, LV end-diastolic and end-systolic dimensions and RWT, and heart/body weight ratio were increased significantly compared to the control group $(p<0.05-0.01)$, while percent FS and EF were decreased significantly. On

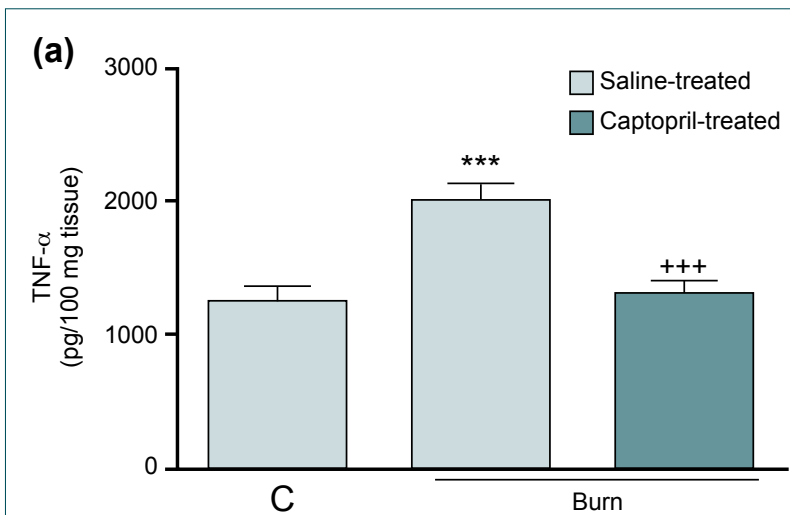

(b)

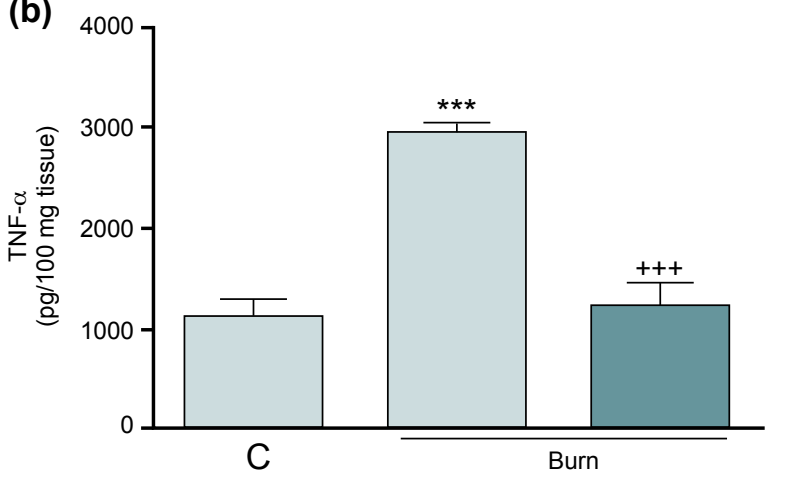

Figure 1. Tumor necrosis factor- $\alpha$ (TNF- $\alpha$ ) levels in the (a) heart and (b) lung tissues of control $(\mathrm{C})$ and saline- or captopril-treated burn groups. Each group consists of 8 animals. ${ }^{* * *}$ : $p<0.001$ : compared to saline-treated control group; +++ : $p<0.001$ : compared to saline-treated burn group. the other hand, in the captopril-treated burn group, echocardiographic measurements were significantly different than those of the saline-treated burn group $(p<0.05)$, but similar to those of the control group.

TNF- $\alpha$ levels in the heart and lung tissues of the saline-treated burn group were significantly increased, while TNF- $\alpha$ levels were found to be decreased in the captopril- treated burn group ( $p<0.00$ I; Figs. Ia, b).

Burn injury caused significant decreases in the GSH levels of the heart and lung tissues of the saline-treated burn group ( $p<0.0 \mathrm{I}-0.00 \mathrm{I})$, but this antioxidant was restored in the captopril-treated burn group ( $p<0.05-0.01$; Figs. 2a, b). On the other hand, MDA levels in both tissues were significantly increased following burn injury ( $p<0.01-0.00 \mathrm{I})$, while treatment with captopril reversed burn-induced elevations in MDA back to the control levels ( $p<0.05-0.01$; Figs. 3a, $b$ ). In the saline-treated burn group, MPO activities in both the heart and lung tissues were increased significantly $(p<0.00 \mathrm{I})$, and treatment with captopril prevented these alterations ( $p<0.01-0.00$ I; Figs. 4a, b).

$\mathrm{Na}^{+}, \mathrm{K}^{+}$-ATPase activities measured in the cardiac and pulmo-
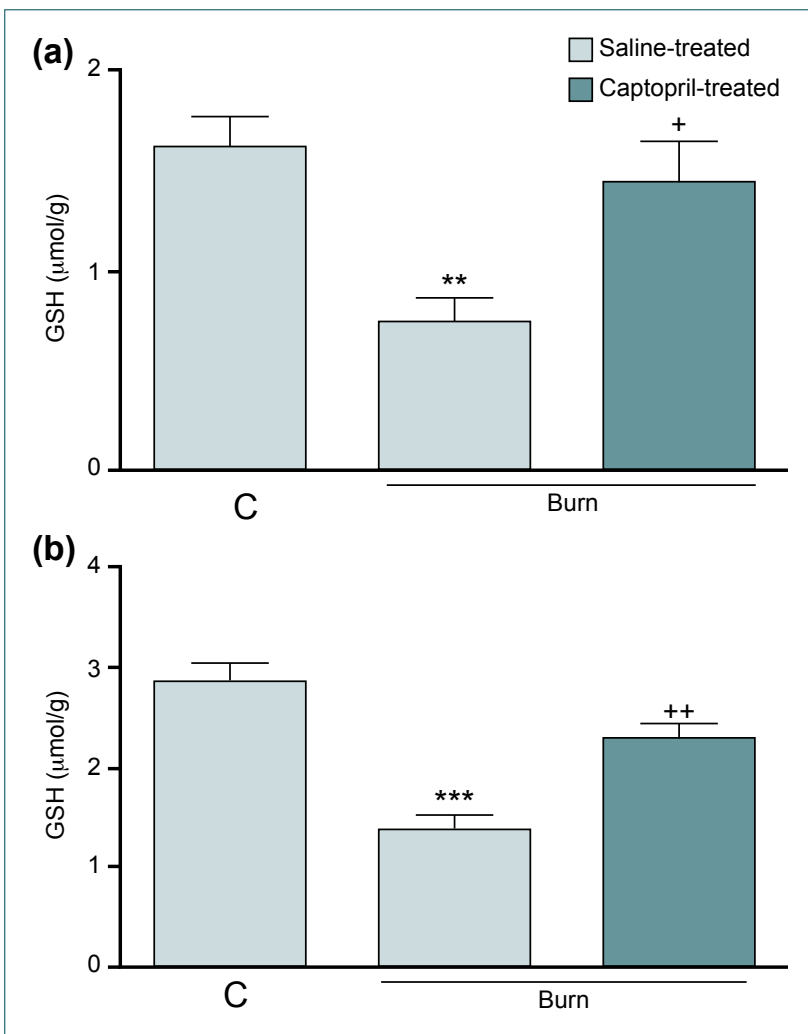

Figure 2. Glutathione (GSH) levels in the (a) heart and (b) lung tissues of control $(C)$ and saline- or captopril-treated burn groups. Each group consists of 8 animals. ${ }^{* *}: p<0.01,{ }^{* * *}: p<0.001$ : compared to saline-treated control group; $+p<0.05,++$ : $p<0.01$ : compared to saline-treated burn group. 

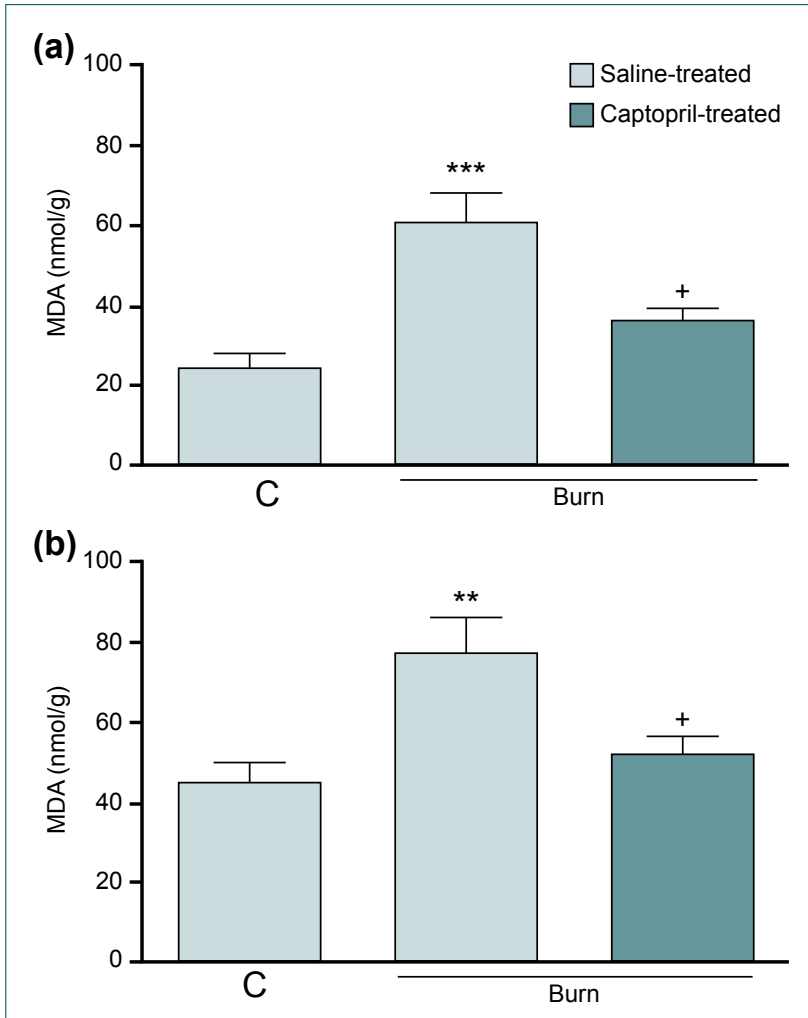

Figure 3. Malondialdehyde (MDA) levels in the (a) heart and (b) lung tissues of control $(C)$ and saline- or captopril-treated burn groups. Each group consists of 8 animals. ${ }^{* *}: p<0.01,{ }^{* * *}: p<0.001$ : compared to saline-treated control group; +: $p<0.05$ : compared to saline-treated burn group.

nary tissues were reduced in the saline-treated burn group $(p<0.00$ I, Figs. $5 a, b)$. In the captopril-treated burned rats, the measured $\mathrm{Na}^{+}, \mathrm{K}^{+}$-ATPase activities in the studied tissues were increased $(p<0.05-0.001)$.

Caspase- 3 activities in both the heart and lung tissues were increased significantly $(p<0.00 \mathrm{I})$, while treatment with captopril reduced these increases $(p<0.01-0.001$; Figs. $6 a, b)$.

Light microscopic evaluation of the cardiac muscle cells in the control group revealed regular nuclei with central alignment (Fig. 7a). In the burn group, the capillaries present in the connective tissue of muscle fibers showed congestion in addition to vacuolization in the cytoplasm of most of the cardiomyocytes (Fig. 7b). On the other hand, in the captopril-treated burn group, vasocongestion was reduced and regular cellular morphology was settled (Fig. 7c).

In lung tissues, the control group demonstrated a welldesignated morphology (Fig. 8a), whereas severe interstitial edema with bronchiolar hemorrhage and stretched alveolar walls were observed in the burn group (Fig. 8b), which was ameliorated by captopril treatment, revealing the reversal of degeneration in the interstitium (Fig. 8c).
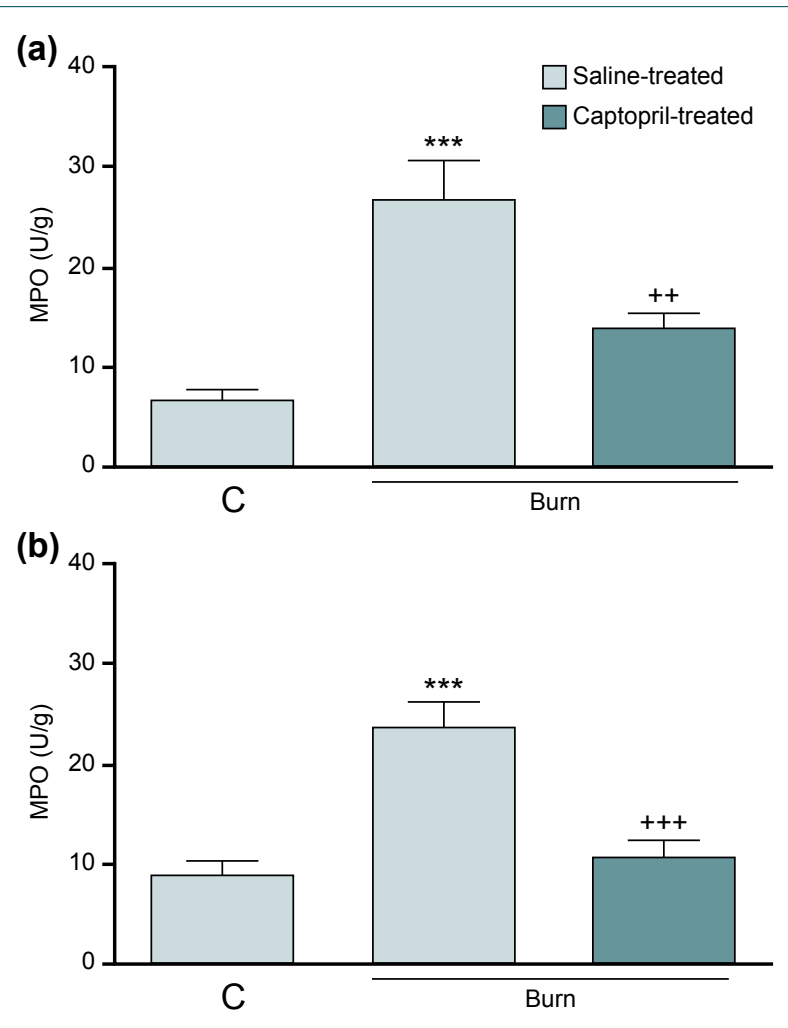

Figure 4. Myeloperoxidase (MPO) activity in the (a) heart and (b) lung tissues of control $(\mathrm{C})$ and saline- or captopril-treated burn groups. Each group consists of 8 animals. ${ }^{* * *}: p<0.001$ : compared to saline-treated control group; ++: $p<0.01$, +++: $p<0.001$ : compared to saline-treated burn group.

\section{DISCUSSION}

The aim of the present work was to explore the effect of captopril, a known ACE inhibitor, on the cardiopulmonary inflammatory process associated with burn in rats.

Thermal trauma is a stressful condition challenging whole body homeostatic mechanisms, accompanied by both local and distant effects leading to intense inflammation, tissue damage and infection. As local production of proinflammatory cytokines will activate non-specific host immunity, tissue injury or infection, cytokines are approached as being important components in the postburn pathophysiological process. ${ }^{[21-23]}$ Accordingly, after thermal trauma, a great many cytokines are induced rapidly, ${ }^{[12,24-27]}$ and ACE mediates inflammation to elicit $\mathrm{T}$ cell stimulation. On the other hand, the ACE inhibitor captopril inhibits conclusive immune functions and attenuates inflammation. ${ }^{[2,29]}$ Our data above demonstrate that burn-induced cardiac and lung injury involve oxidant formation and inflammation, while captopril treatment greatly attenuated these responses. The ability of captopril to protect against thermal trauma was observed with significant decreases in tissue MDA and TNF- $\alpha$ levels and MPO and caspase- 3 activities, which were found to be increased 


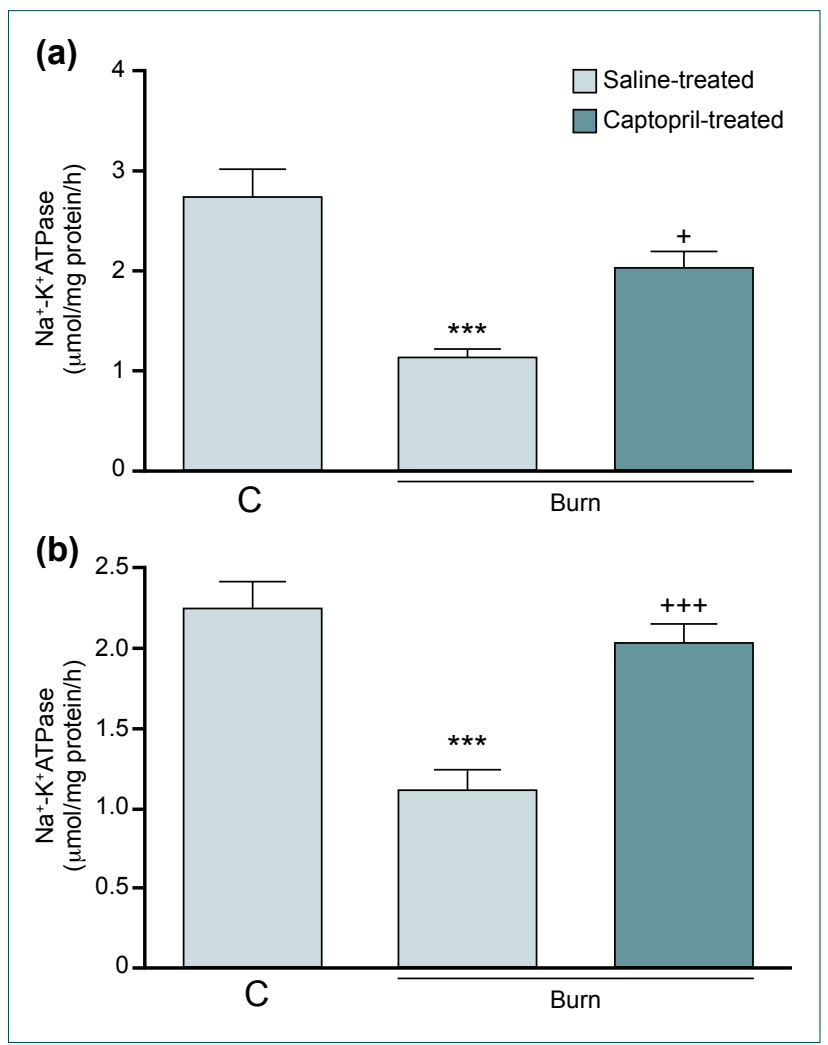

Figure 5. $\mathrm{Na}^{+}-\mathrm{K}^{+}$ATPase activity in the (a) heart and (b) lung tissues of control (C) and saline- or captopril-treated burn groups. Each group consists of 8 animals. ${ }^{* * *}: p<0.001$ : compared to saline-treated control group; +: $p<0.05,+++$ : $p<0.001$ : compared to saline-treated burn group.

following thermal trauma. Furthermore, captopril treatment in the burned rats caused significant increases in both GSH levels and $\mathrm{Na}^{+}, \mathrm{K}^{+}$-ATPase activities, which were found to be depleted in the burn group.

TNF- $\alpha$ is a cytokine excreted by macrophages and monocytes in response to different stimuli, and concentrations were found to be high in patients with heart disease, in association with noticeable activation of the RAS. Levine et al. ${ }^{[30-32]}$ found increased concentrations of TNF- $\alpha$ in heart disease patients with high renin concentrations. In addition, they demonstrated that increased serum TNF- $\alpha$, which plays an essential role in the inflammatory processes, was also decreased with captopril treatment. In our study, following burn injury, increased cytokine TNF- $\alpha$ was associated with impaired cardiac function since in the saline treated-burn group, LVPW, LV end-diastolic and end-systolic dimensions and RWT, and IVS thickness were significantly higher as compared to control rats $(p<0.05-0.01)$, while FS and EF were found to be significantly decreased. Youn et al. ${ }^{[33]}$ studied both ACE inhibition and angiotensin receptor antagonism in a rat model of acute infarction in which transforming growth factor (TGF) beta-I mRNA expression was also increased. Their results demonstrated that both captopril and losartan suppressing the acute induction of TGF-betal
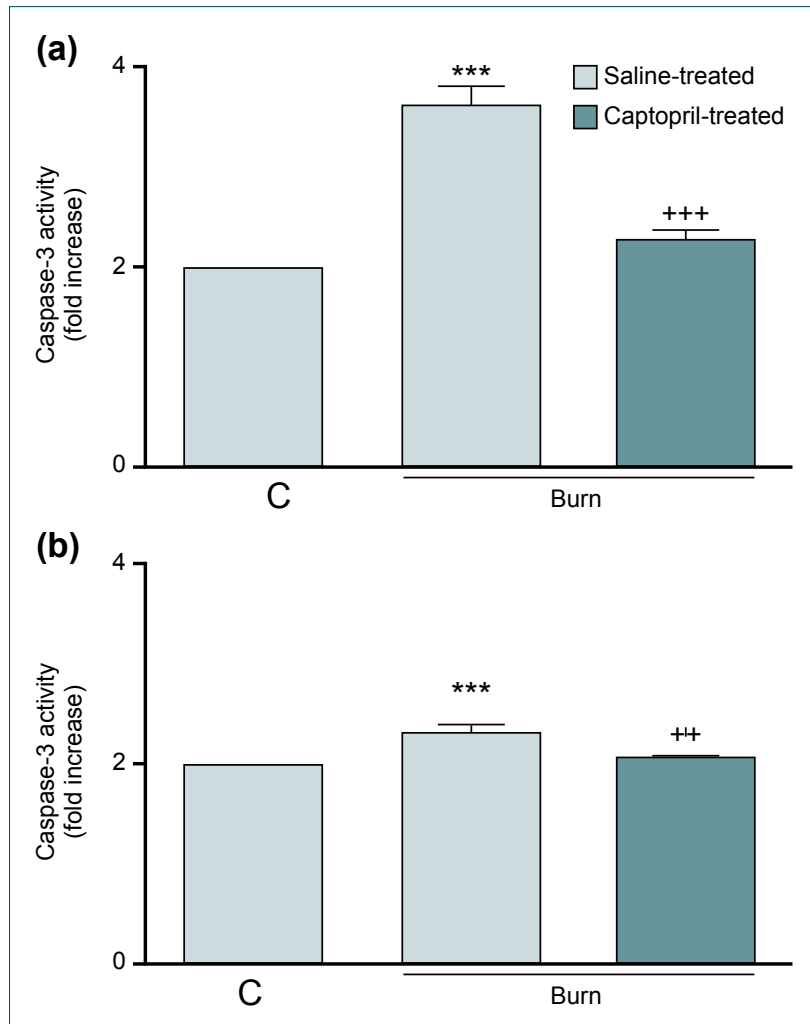

Figure 6. Caspase-3 activity in the (a) heart and (b) lung tissues of control $(\mathrm{C})$ and saline- or captopril-treated burn groups. Each group consists of 8 animals. ${ }^{* *}: p<0.001$ : compared to saline-treated control group; ++: $p<0.01,+++$ : $p<0.001$ : compared to salinetreated burn group.

mRNA expressions attenuated LV remodeling. Captopril has been shown to express immune-regulating, antioxidant and anti-inflammatory properties. ${ }^{[34]}$ In agreement with these studies, our results showed that depressing cytokine expression is associated with improved cardiac function.

Major burn injuries can lead to life-threatening end-organ dysfunction including cardiac dysfunction, which is a major contributor to mortality. ${ }^{[3,36]}$ Despite prompt and adequate fluid replacement following burn injury, alterations in cardiovascular function such as reduced cardiac output, myocardial inflammation and an intrinsic defect in myocardial performance can cause multiple organ dysfunction syndrome. Numerous experimental studies have been performed to identify the molecular mechanisms involved in burn-related cardiac dysfunction with the end goal of creating novel therapeutic interventions and agents to reduce the incidence of life-threatening complications. ${ }^{[37,38]}$ In our study, by improving cardiac function, captopril protected cardiac and lung tissues since oxidative injury observed through MDA and GSH levels and MPO, $\mathrm{Na}^{+}, \mathrm{K}^{+}$-ATPase and caspase activities were reversed in both tissues. One of the causative agents accountable for the development of burn shock and distant organ damage in animal models of burn injury are oxygen radicals. ${ }^{[27]}$ 

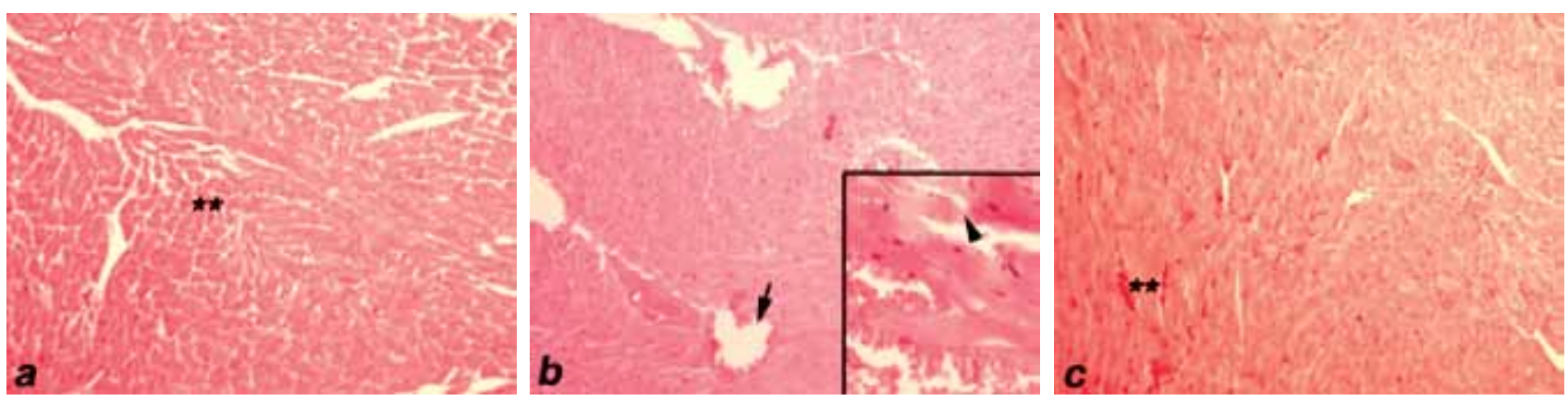

Figure 7. (a) Control group: regular alignment of muscle cells with centrally located nuclei $\left.{ }^{* *}\right)$. (b) Burn group: capillary vasocongestion among the connective tissue of the muscle cells (arrow), vacuolization in the cytoplasm of the cardiac muscle cells and degeneration of some gapjunctions (arrowhead). (c) Burn and captopril treatment: the capillary vasocongestion was reduced, and vacuolization in the cytoplasm of the cells was decreased $\left({ }^{* *}\right), \mathrm{H} \& E$ staining, $x 200$, insets $x 400$.
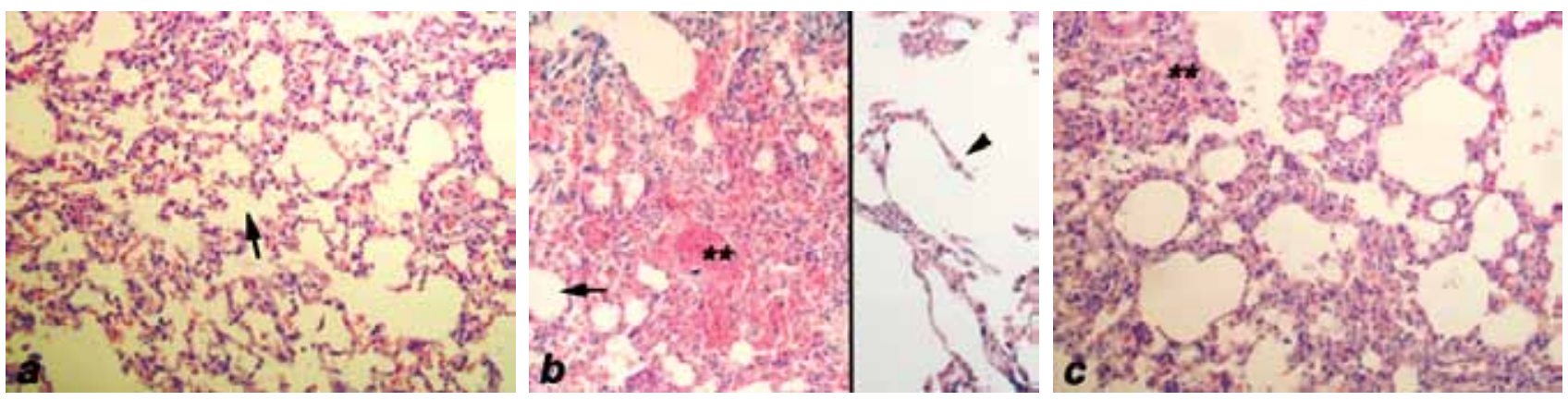

Figure 8. (a) Control group demonstrated a regular alveolar structure (arrow) with no distention in its walls. (b) Burn group, severe congestion $\left({ }^{* *}\right)$ and interstitial edema, which led to a decrease in alveolar space (arrow) in most areas of the tissue. In some regions, the alveoli united with each other resulting in large distended alveolar spaces (arrowhead-inset). (c) Burn and captopril group: reduced interstitial congestion and edema $\left({ }^{* *}\right)$ and expanded alveolar areas and no congestion present.

The distant organs involved in the thermal damage during experimental skin burn are thought to be the lungs, heart, liver, kidney, and gastrointestinal mucosa. In all cases of thermal trauma, neutrophils diffuse these organs, being the potent source of reactive oxygen metabolites. ${ }^{[39]}$ As is known, accumulation and activation of neutrophils induce tissue damage and release of different cytotoxic proteins into the extracellular fluid. MPO activity, an indirect marker of neutrophil infiltration, ${ }^{[40]}$ has been shown to be significantly increased in various tissues of burned rats. ${ }^{[12,4]}$ Similarly, in the present study, increased MPO activity in both heart and lung tissues suggests that neutrophil accumulation in these tissues assist in organ injury distant from the original wound. On the other hand, in the captopril- treated burn groups, MPO activities were reduced. The effects of captopril on MPO activity were studied previously in different experimental models of inflammation. Leor et al. ${ }^{[42]}$ studied the effects of captopril experimentally, and proposed that captopril did not decrease neutrophil-induced myocardial injury following coronary occlusion and reperfusion. Nonetheless, Van Antwerpen et al. ${ }^{[43]}$ in their in vitro study showed that captopril, by inhibiting the $\mathrm{MPO} / \mathrm{HOCl}$ system, was able to significantly reduce the oxidative modification of low-density lipoprotein in a dosedependent manner. Furthermore, $\mathrm{Li}$ et al. ${ }^{[4]}$ demonstrated that pathological injury of the lung in rats with intense acute pancreatitis was decreased with captopril treatment.

Malondialdehyde (MDA), an end product of lipid peroxidation, is major evidence of lipid peroxidation, and in this study, its levels were found to be significantly advanced due to burn in both heart and lung tissues. Results from animal and human studies suggested that there is a relationship between tissue MDA levels and the degree of burn complications, including shock and remote organ damage. ${ }^{[25,41,45,46]}$ Our results showed that captopril treatment in the burned rats caused significant reduction in MDA.

Esterified GSH is a significant component of the cellular antioxidant system. The GSH molecule acts as an electron acceptor for hydrogen peroxide by forming an oxidized thiol and then undergoing degradation by glutathione reductase. ${ }^{[4]}$ In a previous study, GSH levels have been reported to be decreased in the lung, liver and kidney of rats after burn. ${ }^{[12,25,26,28,45]}$ In this study, lessening effects of captopril on MDA concurred with preservation of tissue GSH level, which is an important antioxidant. Moreover, Gurer et al., ${ }^{[48]}$ studying GSH, suggested that captopril has a promising beneficial role in augmenting the reducing capacity of the cells by increasing GSH. 
Apoptosis is an orchestrated form of cell 'death by suicide'. It is principal in both the development and normal continuation of tissue function. Apoptotic nerve cell death is related to the pathogenesis of several devastating neurodegenerative diseases. Recently, apoptosis was found to be important in the pathophysiological changes occurring after major burns. After thermal injuries, nearly every organ or tissue seems affected and manifests this peculiar cellular mechanism characterizing a "systemic apoptotic response". ${ }^{[49]}$ Currently, ROS may mediate apoptosis through the starting of poly (ADPribose) polymerase (PARP), advances in mitochondrial permeability with the release of cytochrome $C$, and activation of caspases. ${ }^{[50,51]}$ ROS-triggered release of lysosomal ingredients can also lead to apoptosis. Hydrogen peroxide can freely diffuse across cell membranes, including the lysosomal membrane. Inside the lysosome, hydrogen peroxide can react with iron to form the potent hydroxide radical, at least causing damage to the lysosomal membrane and leakage of contents. The translocation of the protease cathepsin D from the lysosome to the cytosol yields to the induction of apoptosis. ${ }^{[52]}$ Since captopril has recently been found to inhibit Fas-induced apoptosis in human-activated $\mathrm{T}$ cells ${ }^{[53]}$ and lung epithelial cells, ${ }^{[54]}$ we hypothesized that suppression of apoptosis could be one of the mechanisms bringing about the efficacy of ACE inhibitors. In the present study, we examined the apoptosis measuring caspase- 3 activity in the heart and lung tissues, and found that thermal trauma increased heart and lung apoptosis. On the other hand, captopril treatment effectively lessened caspase- 3 activity and protected tissues, as also confirmed histologically.

$\mathrm{Na}^{+}, \mathrm{K}^{+}$-ATPase is a considerable membrane protein that carries out the coupled extrusion and uptake of $\mathrm{Na}^{+}$and $\mathrm{K}^{+}$ ions across the plasma membranes. As the activity of $\mathrm{Na}^{+}$, $\mathrm{K}^{+}$-ATPase, a membrane-bound enzyme required for cellular transport, is very sensitive to free radical reactions and lipid peroxidation, decrease in this activity can show membrane damage indirectly. $\mathrm{Na}^{+}, \mathrm{K}^{+}$-ATPase activities measured in the cardiac and pulmonary tissues were reduced in the saline-treated rats $(p<0.001)$, indicating damaged transport function in these tissues (Fig. 5a, 5b). In the captopril-treated burned rats, the measured $\mathrm{Na}^{+}, \mathrm{K}^{+}$-ATPase activities in the studied tissues were increased compared to those of the control rats $(p<0.05-0.001)$. Ottlecz et al. ${ }^{[55]}$ demonstrated that stimulation of retinal $\mathrm{Na}^{+}, \mathrm{K}^{+}$-ATPase activity in diabetes is most likely one of the mechanisms through which captopril can improve retinal complications. Our study has shown that $\mathrm{Na}^{+}, \mathrm{K}^{+}$-ATPase activities were significantly reduced in both cardiac and lung tissues of burned rats, while captopril treatment significantly protected the enzyme activity.

In conclusion, the findings of the present study demonstrated that captopril treatment protected multiorgan damage in thermal trauma through inhibition of pro-inflammatory and oxidative pathways. Furthermore, captopril treatment provided regular cellular morphology in lung and heart tissues, which caused a concomitant decrease in lipid peroxidation and increase in tissue antioxidant defense. Therefore, these results suggest an anti-inflammatory, cardiopulmonary protective effect of captopril, with a reduction in the circulating proinflammatory markers and an increase in those antiinflammatory cytokines; these effects result in a benefit on the cardiopulmonary inflammatory process associated with burninduced thermal trauma. Thus, captopril treatment merits consideration as a potential therapeutic agent for restoring organ damage following thermal trauma.

\section{Conflict of interest: None declared.}

\section{REFERENCES}

1. Chandran PK, Kuttan R. Effect of Calendula officinalis Flower Extract on Acute Phase Proteins, Antioxidant Defense Mechanism and Granuloma Formation During Thermal Burns. J Clin Biochem Nutr 2008;43:5864.

2. Parihar A, Parihar MS, Milner S, Bhat S. Oxidative stress and anti-oxidative mobilization in burn injury. Burns 2008;34:6-17.

3. Horton JW, Garcia NM, White DJ, Keffer J. Postburn cardiac contractile function and biochemical markers of postburn cardiac injury. J Am Coll Surg 1995;181:289-98.

4. Mueller M, Sartorelli K, DeMeules JE, Gamelli RL. Effects of fluid resuscitation on cardiac dysfunction following thermal injury. J Surg Res 1988;44:745-53.

5. Adams HR, Baxter CR, Izenberg SD. Decreased contractility and compliance of the left ventricle as complications of thermal trauma. Am Heart J 1984;108:1477-87.

6. Gao S, Chen ZW, Zheng H, Chen XL. Ligustrazine attenuates acute myocardium injury after thermal trauma. Burns 2007;33:321-7.

7. de Kloet AD, Krause EG, Woods SC. The renin angiotensin system and the metabolic syndrome. Physiol Behav 2010;100:525-34.

8. Bhuyan BJ, Mugesh G. Synthesis, characterization and antioxidant activity of angiotensin converting enzyme inhibitors. Org Biomol Chem 2011;9:1356-65.

9. Kubota M, Shimizu M, Sakai H, Yasuda Y, Ohno T, Kochi T, et al. Renin-angiotensin system inhibitors suppress azoxymethane-induced colonic preneoplastic lesions in C57BL/KsJ-db/db obese mice. Biochem Biophys Res Commun 2011;410:108-13.

10. Molteni A, Ward WF, Tśao CH, Taylor J, Small W Jr, Brizio-Molteni $\mathrm{L}$, et al. Cytostatic properties of some angiotensin I converting enzyme inhibitors and of angiotensin II type I receptor antagonists. Curr Pharm Des 2003;9:751-61.

11. Bagchi D, Prasad R, Das DK. Direct scavenging of free radicals by captopril, an angiotensin converting enzyme inhibitor. Biochem Biophys Res Commun 1989;158:52-7.

12. Sener G, Sehirli AO, Satiroğlu H, Keyer-Uysal M, C Yeğen B. Melatonin improves oxidative organ damage in a rat model of thermal injury. Burns 2002;28:419-25.

13. Ripley EB, Gehr TW, Kish CW, Sica DA. Hormonal, blood pressure, and peritoneal transport response to short-term ACE inhibition. Perit Dial Int 1994;14:378-83.

14. Schiller NB, Shah PM, Crawford M, DeMaria A, Devereux R, Feigenbaum $\mathrm{H}$, et al. Recommendations for quantitation of the left ventricle by two-dimensional echocardiography. American Society of Echocardiography Committee on Standards, Subcommittee on Quantitation of Two- 
Dimensional Echocardiograms. J Am Soc Echocardiogr 1989;2:358-67.

15. Buege JA, Aust SD. Microsomal lipid peroxidation. Methods Enzymol 1978;52:302-10.

16. Beutler E. Glutathione in red blood cell metabolism. A manual of biochemical methods. E Beutler (editor). New York: Grune\&Stratton; 1975. p. 112-4.

17. Hillegass LM, Griswold DE, Brickson B, Albrightson-Winslow C. Assessment of myeloperoxidase activity in whole rat kidney. J Pharmacol Methods 1990;24:285-95.

18. Reading HW, Isbir T. The role of cation-activated ATPases in transmitter release from the rat iris. QJ Exp Physiol Cogn Med Sci 1980;65:10516.

19. Fiske $\mathrm{CH}$, Subbarow $\mathrm{Y}$. The colorimetric determination of phosphorus. J Biol Chem 1925;66:375-400.

20. LOWRY OH, ROSEBROUGH NJ, FARR AL, RANDALL RJ. Protein measurement with the Folin phenol reagent. J Biol Chem 1951;193:265-75.

21. Ravage ZB, Gomez HF, Czermak BJ, Watkins SA, Till GO. Mediators of microvascular injury in dermal burn wounds. Inflammation 1998;22:619. 29.

22. Yeh FL, Lin WL, Shen HD. Changes in circulating levels of an anti-inflammatory cytokine interleukin 10 in burned patients. Burns 2000;26:454-9.

23. Summer GJ, Romero-Sandoval EA, Bogen O, Dina OA, Khasar SG, Levine JD. Proinflammatory cytokines mediating burn-injury pain. Pain 2008;135:98-107.

24. Sener G, Sehirli AO, Gedik N, Dülger GA. Rosiglitazone, a PPARgamma ligand, protects against burn-induced oxidative injury of remote organs. Burns 2007;33:587-93.

25. Sehirli O, Sener E, Sener G, Cetinel S, Erzik C, Yeğen BC. Ghrelin improves burn-induced multiple organ injury by depressing neutrophil infiltration and the release of pro-inflammatory cytokines. Peptides 2008;29:1231-40.

26. Wang G, Tian J, Tang H, Zhu S, Huan J, Ge S, et al. The role of Kupffer cells on the postburn production of TNFalpha, IL-1beta and IL-6 in severely scalded rats. [Article in Chinese] Zhonghua Shao Shang Za Zhi 2002;18:282-4. [Abstract]

27. Demiralay E, Saglam IY, Ozdamar EN, Sehirli AO, Sener G, Saglam E. nNOS expression in the brain of rats after burn and the effect of the ACE inhibitor captopril. Burns 2012. pii: S0305-4179(12)00328-2.

28. Constantinescu CS, Ventura E, Hilliard B, Rostami A. Effects of the angiotensin converting enzyme inhibitor captopril on experimental autoimmune encephalomyelitis. Immunopharmacol Immunotoxicol 1995;17:471-91.

29. Jerng JS, Hsu YC, Wu HD, Pan HZ, Wang HC, Shun CT, et al. Role of the renin-angiotensin system in ventilator-induced lung injury: an in vivo study in a rat model. Thorax 2007;62:527-35.

30. Dutka DP, Elborn JS, Delamere F, Shale DJ, Morris GK. Tumour necrosis factor alpha in severe congestive cardiac failure. Br Heart J 1993;70:1413.

31. Levine B, Kalman J, Mayer L, Fillit HM, Packer M. Elevated circulating levels of tumor necrosis factor in severe chronic heart failure. $\mathrm{N}$ Engl J Med 1990;323:236-41.

32. Miguel-Carrasco JL, Zambrano S, Blanca AJ, Mate A, Vázquez CM. Captopril reduces cardiac inflammatory markers in spontaneously hypertensive rats by inactivation of NF-kB. J Inflamm (Lond) 2010;7:21.

33. Youn TJ, Kim HS, Oh BH. Ventricular remodeling and transforming growth factor-beta $1 \mathrm{mRNA}$ expression after nontransmural myocardial infarction in rats: effects of angiotensin converting enzyme inhibition and angiotensin II type 1 receptor blockade. Basic Res Cardiol 1999;94:24653.

34. Albuquerque D, Nihei J, Cardillo F, Singh R. The ACE inhibitors enalapril and captopril modulate cytokine responses in $\mathrm{Balb} / \mathrm{c}$ and $\mathrm{C} 57 \mathrm{Bl} / 6$ normal mice and increase CD4(+)CD103(+)CD25(negative) splenic $\mathrm{T}$ cell numbers. Cell Immunol 2010;260:92-7.

35. Lang CH, Frost RA, Vary TC. Thermal injury impairs cardiac protein synthesis and is associated with alterations in translation initiation. Am J Physiol Regul Integr Comp Physiol 2004;286:R740-50.

36. Lupia E, Spatola T, Cuccurullo A, Bosco O, Mariano F, Pucci A, et al. Thrombopoietin modulates cardiac contractility in vitro and contributes to myocardial depressing activity of septic shock serum. Basic Res Cardiol 2010;105:609-20.

37. Zang QS, Maass DL, Wigginton JG, Barber RC, Martinez B, Idris $\mathrm{AH}$, et al. Burn serum causes a $\mathrm{CD} 14$-dependent mitochondrial damage in primary cardiomyocytes. Am J Physiol Heart Circ Physiol 2010;298:H1951-8.

38. Xiao R, Lei ZY, Dang YM, Huang YS. Prompt myocardial damage contributes to hepatic, renal, and intestinal injuries soon after a severe burn in rats. J Trauma 2011;71:663-72.

39. Marciniak A, Szpringer E, Lutnicki K, Beltowski J. Influence of early excission of burn wound on the lipid peroxidation in selected rat tissues. Bull Vet Pulawy 2002;46:255-65.

40. Bradley PP, Priebat DA, Christensen RD, Rothstein G. Measurement of cutaneous inflammation: estimation of neutrophil content with an enzyme marker. J Invest Dermatol 1982;78:206-9.

41. Işeri SO, Gedik IE, Erzik C, Uslu B, Arbak S, Gedik N, et al. Oxytocin ameliorates skin damage and oxidant gastric injury in rats with thermal trauma. Burns 2008;34:361-9.

42. Leor J, Varda-Bloom N, Hasdai D, Ovadia Z, Battler A. Failure of captopril to attenuate myocardial damage, neutrophil accumulation, and mortality following coronary artery occlusion and reperfusion in rat. Angiology 1994;45:717-24.

43. Van Antwerpen P, Legssyer I, Zouaoui Boudjeltia K, Babar S, Moreau $\mathrm{P}$, Moguilevsky N, et al. Captopril inhibits the oxidative modification of apolipoprotein B-100 caused by myeloperoxydase in a comparative in vitro assay of angiotensin converting enzyme inhibitors. Eur J Pharmacol 2006;537:31-6

44. Li SL, Chen X, Zhang XW, Wu T, Ji ZZ. Protective effects of captopril against lung injury in rats with severe acute pancreatitis. [Article in Chinese] Nan Fang Yi Ke Da Xue Xue Bao 2010;30:2742-5. [Abstract]

45. Sener G, Kabasakal L, Cetinel S, Contuk G, Gedik N, Yeğen BC. Leukotriene receptor blocker montelukast protects against burn-induced oxidative injury of the skin and remote organs. Burns 2005;31:587-96.

46. Sabry A, Wafa I, El-Din AB, El-Hadidy AM, Hassan M. Early markers of renal injury in predicting outcome in thermal burn patients. Saudi J Kidney Dis Transpl 2009;20:632-8.

47. Ballatori N, Krance SM, Notenboom S, Shi S, Tieu K, Hammond CL. Glutathione dysregulation and the etiology and progression of human diseases. Biol Chem 2009;390:191-214.

48. Gurer H, Neal R, Yang P, Oztezcan S, Ercal N. Captopril as an antioxidant in lead-exposed Fischer 344 rats. Hum Exp Toxicol 1999;18:27-32.

49. Gravante G, Delogu D, Sconocchia G. "Systemic apoptotic response" after thermal burns. Apoptosis 2007;12:259-70.

50. Shupp JW, Nasabzadeh TJ, Rosenthal DS, Jordan MH, Fidler P, Jeng JC. A review of the local pathophysiologic bases of burn wound progression. J Burn Care Res 2010;31:849-73.

51. Gibran NS, Heimbach DM. Current status of burn wound pathophysiology. Clin Plast Surg 2000;27:11-22. 
52. Roberg K, Ollinger K. Oxidative stress causes relocation of the lysosomal enzyme cathepsin $\mathrm{D}$ with ensuing apoptosis in neonatal rat cardiomyocytes. Am J Pathol 1998;152:1151-6.

53. Déas O, Dumont C, Mollereau B, Métivier D, Pasquier C, Bernard-Pomier G, et al. Thiol-mediated inhibition of FAS and CD2 apoptotic signaling in activated human peripheral T cells. Int Immunol 1997;9:117-25.
54. Uhal BD, Gidea C, Bargout R, Bifero A, Ibarra-Sunga O, Papp M, et al. Captopril inhibits apoptosis in human lung epithelial cells: a potential antifibrotic mechanism. Am J Physiol 1998;275:L1013-7.

55. Ottlecz A, Bensaoula T. Captopril ameliorates the decreased $\mathrm{Na}+, \mathrm{K}(+)$ ATPase activity in the retina of streptozotocin-induced diabetic rats. Invest Ophthalmol Vis Sci 1996;37:1633-41.

DENEYSEL ÇALIŞMA - ÖZET

\title{
Sıçanlarda yanıkla uyarılan kardiyopulmoner hasara karşı kaptoprilin koruyucu etkisi
}

Dr. Esra Sağlam, ${ }^{1}$ Ahmet Özer Şehirli, ${ }^{2}$ Emine Nur Özdamar, ${ }^{3}$ Gazi Contuk, ${ }^{4}$ Şule Çetinel, ${ }^{4}$ Derya Özsavcı, ${ }^{5}$ Selami Süleymanoğlu, ${ }^{6}$ Göksel Şener ${ }^{2}$

\author{
${ }^{1}$ Maltepe Üniversitesi Tıp Fakültesi, Farmakoloji ve Klinik Farmakoloji Anabilim Dalı, İstanbul \\ ${ }^{2}$ Marmara Üniversitesi Eczacılık Fakültesi, Farmakoloji Anabilim Dalı, İstanbul \\ ${ }^{3}$ Marmara Üniversitesi Tıp Fakültesi, Tıbbi Farmakoloji Anabilim Dalı, İstanbul \\ ${ }^{4}$ Marmara Üniversitesi Tıp Fakültesi, Histoloji ve Embriyoloji Anabilim Dalı, İstanbul \\ ${ }^{5}$ Marmara Üniversitesi Eczacılık Fakültesi, Biokimya Anabilim Dalı, İstanbul \\ ${ }^{6}$ Gülhane Askeri Tıp Akademisi, Kardiyoloji Anabilim Dalı, İstanbul
}

AMAÇ: Bu çalışma, kalp ve akciğer dokularında yanıkla uyarılan oksidatif hasara karşı kaptopril tedavisinin olası koruyucu etkisini saptamak için tasarlandı.

GEREÇ VE YÖNTEM: Eter anestezisi altında sırt derileri traş edilen Wistar albino türü sıçanlar 10 saniye süreyle $90^{\circ} \mathrm{C}$ suya tutuldu. Yanık hasarından sonra ve 12 saat sonra olmak üzere $10 \mathrm{mg} / \mathrm{kg}$ intraperitoneal kaptopril uygulandı. Kontrol grubunda ise sıçanların sırtı 10 saniye süreyle $25^{\circ} \mathrm{C}$ suya tutuldu. Yanık hasarından 24 saat sonra ekokardiyografik kayıtları alınan sıçanlar dekapite edildi ve kalp ve akciğer doku örnekleri çıkartılarak tümör nekroz faktör- $\alpha$ (TNF- $\alpha$ ), malondialdehit ve glutatyon düzeyleri, miyeloperoksidaz, kaspaz-3 ve $\mathrm{Na}^{+}, \mathrm{K}^{+}-\mathrm{ATPaz}$ aktiviteleri tayini ile histolojik analizler yapıldı.

BULGULAR: Yanık sol ventrikül fonksiyonlarında önemli değişikliklere neden oldu. Kalp ve akciğer dokularında yanık hasarına bağlı olarak glutatyon düzeyleri ve $\mathrm{Na}^{+}, \mathrm{K}^{+}-\mathrm{ATPaz}$ aktivitelerinin azaldığı ve TNF- $\alpha$ ve malondialdehit düzeyleri ile miyeloperoksidaz ve kaspaz-3 aktivitelerinin arttığı bulundu. Kaptopril tedavisinin, azalmış glutatyon düzeyi ve $\mathrm{Na}^{+}, \mathrm{K}+$-ATPaz aktivitesini anlamlı düzeyde yükselttiği ve sitokin ve malondialdehit düzeyleri ve miyeloperoksidaz ve kaspaz-3 aktivitelerini ise anlamlı düzeyde azalttığı bulundu.

TARTIŞMA: Kaptopril kalp ve akciğer dokularında yanıkla uyarılan hasarı̈ önler ve oksidatif organ hasarına karşı korur.

Anahtar sözcükler: Kaptopril; lipid peroksidasyonu; miyeloperoksidaz; sitokin; yanık.

Ulus Travma Acil Cerrahi Derg 20।4;20(3): I5I-I60 doi: I0.5505/tjtes.20।4.96493 